\title{
FREE DENTAL CARE FOR UNDER 16S IN THE
REPUBLIC OF IRELAND
}

BIGGEST

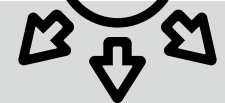
OVERSPEND IN NHS HISTORY

King's College Hospital NHS Foundation Trust has recorded an annual deficit of between $£ 180 \mathrm{~m}$ and $£ 191 \mathrm{~m}$ - the biggest overspend in NHS history. The trust is struggling with the most serious financial problems in the NHS as a result of a private finance initiative (PFI) contract, high use of agency staff to cover its chronic lack of nurses, and being fined for missing the four-hour A\&E target.

A spokesperson for King's College Hospital Trust is quoted on the National Health Executive website saying: 'Our current financial forecast is higher than that planned this time last year. However, over the past year, a number of changes have been implemented that will enable the trust to improve its productivity and stabilise its longer-term stability.'

'Despite the financial challenges, the trust continues to deliver excellent, highquality care and services to patients.'

\section{DONCASTER} DENTAL TEAM PUT ON FULL PAY 'GARDENING LEAVE' BY NHS

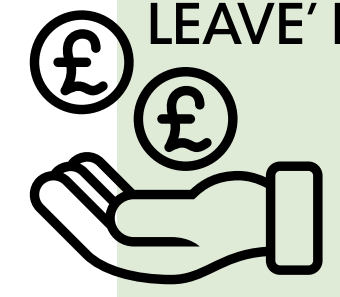

An emergency dental service in Doncaster has been closed after a private company failed to take over the contracts.

Meanwhile, over 20 staff from the former NHS dental surgery are still being paid.

The private corporate group Dental Partners won the NHS England service. Rotherham NHS Foundation Trust, who previously had the contract, declined to re-tender due to financial reasons.

The decision to move the staff over was taken last year, but staff were only informed of the move at the end of January. The Transfer of Undertakings (Protection of Employment) process, more commonly known as TUPE, failed to materialise which means staff face now an uncertain future.

Guaranteed funding is essential if a new plan launched by the Irish Government to provide free treatment to under $16 \mathrm{~s}$ is going to work. This is according to the Irish Dental Association.

The plan, called Smile agus Sláinte, is due to be phased in from this year until 2026 and was launched by the Republic's Department of Health. It aims to provide preventative oral health services to children up to 16 and medical card holders.

Under the policy there would be a package of free services including dental exams,

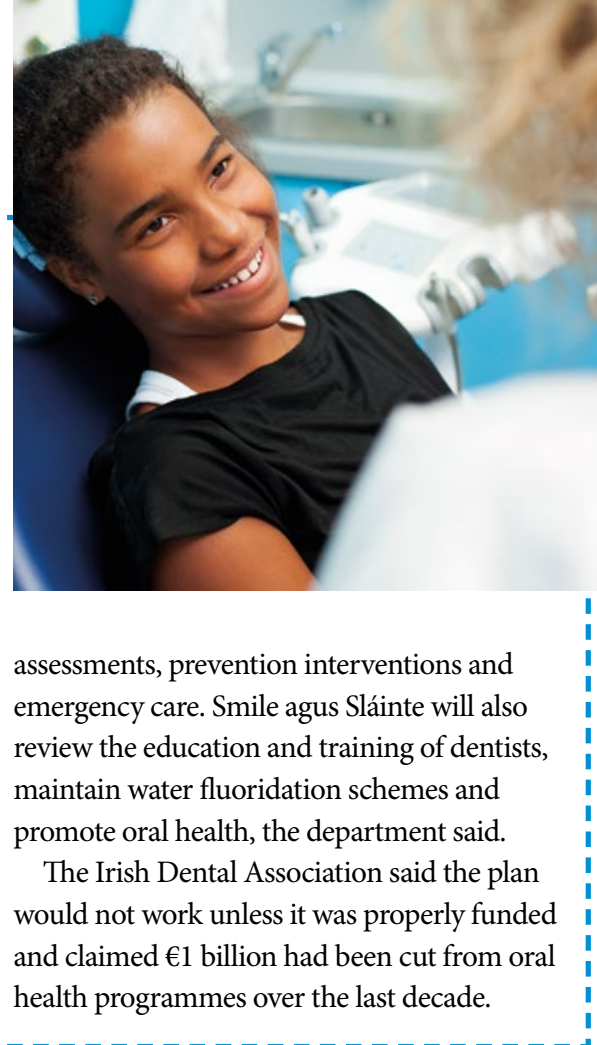

\section{Bad diets killing more people globally than tobaceo, study finds}

Unhealthy diets are responsible for $11 \mathrm{~m}$ preventable deaths globally per year, more even than smoking tobacco, according to a major study. But the biggest problem is not the junk we eat but the nutritious food we don't eat, say researchers, calling for a global shift in policy to promote vegetables, fruit, nuts and legumes. While sugar and transfats are harmful, more deaths are caused by the absence of healthy foods in our diet, the study found. The research is part of the Global Burden of Disease study by the Institute of Health Metrics and Evaluation (IHME) in Seattle, published in the Lancet medical journal. Heart attacks and strokes are the main diet-related causes of death, followed by cancers and Type 2 diabetes, say researchers. The study found that eating and drinking better could prevent one in five deaths around the world.

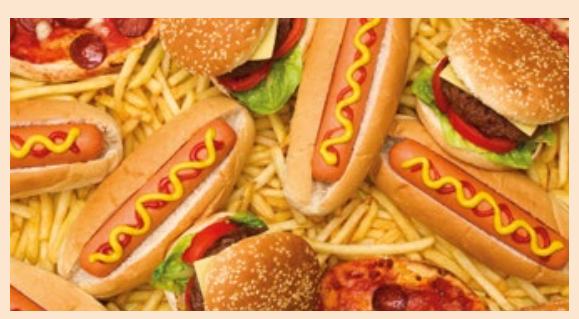

\section{HIKE IN CQC FEE IS 'UNFAIR'}

The Care Quality Commission (CQC), has increased its regulatory fees for dentists in England from 1 April 2019 by $13 \%$ - the equivalent of an additional $£ 0.6$ million.

The move has been condemned by the $\mathrm{BDA}$, which said it was unfair given that the regulator consistently reported that dental practices, when compared with all other sectors, presented the lowest risk to patient safety.

The new fees will increase costs for singlelocation and domiciliary dental care providers by $£ 69-£ 149$, depending on the number of dental chairs, with fees for multiple-location providers rising by the same proportions.

The BDA said it did not believe that the CQC had demonstrated adequately that there was a gap between CQC costs and fees recovered of $£ 2$ million. Given that dentistry was estimated to account for only $4.5 \%$ of the CQC's costs (but $20 \%$ of its registrants), the BDA questioned why dentists were expected to pay $20 \%$ of the Commission's overheads.

It also questioned why corporates would continue to pay proportionally less per surgery than the average high street provider.

The Faculty of General Dental Practice (FGDP(UK)) also condemned the fee increase and its Dean, Ian Mills said: 'In view of the highly positive reports the Commission has delivered on the dental sector in recent years, dentists will find a further increase in fees this year particularly bewildering and unwelcome.' 